\title{
Cultural Value Transformation in Traditional Market Spatial Planning in City of Denpasar, Gianyar and Klungkung - Bali, Indonesia
}

\author{
Widiastuti ${ }^{1}$, Syamsul Alam Paturusi ${ }^{1} \&$ Ngakan Ketut Acwin Dwijendra ${ }^{1}$ \\ ${ }^{1}$ Department of Architecture, University of Udayana, Bali, Indonesia \\ Correspondence: Widiastuti, Department of Architecture, University of Udayana, Bali, Indonesia. Tel: \\ 62-3-6170-3385. E-mail: acwin@unud.ac.id
}

Received: June 2, 2017

doi:10.5539/jsd.v10n4p97
Accepted: July 18, $2017 \quad$ Online Published: July 30, 2017

URL: https://doi.org/10.5539/jsd.v10n4p97

\begin{abstract}
The purpose of this study is to determine the cultural values that underlie the formation of traditional market spatial patterns. In this research will be studied traditional market spatial pattern, change-morphology, hidden cultural values in the form of the morphology, and the factors that cause change. This research takes place in traditional markets in the city of Denpasar, Gianyar, and Klungkung, Bali Indonesia. This research uses descriptive qualitative method with multi layer mapping technique and interview. The results of this study indicate that the morphology of traditional markets on a city scale is one of the three pillars of palace power: political, economic and cultural. At footprint scale of the traditional market morphology is a transformation of the conception of the spatial value of traditional Balinese space that places the function of the purity zones. From the beginning of the formation of the market there are some morphological changes both on the scale of the city and the scale of the site, especially with regard to the placement of the shrine. The main factors causing the change are political and cultural change. Political factors started in the fall of the castle into the hands of the invaders and the cultural factor is the community's attempt to restore the market zoning to a more appropriate traditional spatial conception.
\end{abstract}

Keywords: traditional markets, spatial morphology, cultural values, spatial planning

\section{Introduction}

The market is one of many systems, institutions, procedures, social relationships, and infrastructure in which trade people, goods and services are exchanged, form part of the economy. Traditional markets are government-run markets and more segmented to middle-class people. Traditional market is a place to accommodate trading activities and trade-related transactions, where most of them provide daily necessities, which are still bargaining process and usually consist of small and medium traders. The building consists of kiosks, stalls and open areas. Market as a trading center/place of economy transaction ; which is generally in the form of wantilan (multi fuction) or simple building (Noor 1999).

The market was originally a traditional economic facility, which is the center of community commerce activities, besides the main function of the market as a place where trade economic activity takes place, the market also carries out missions as a vehicle for social and recreational activities. The market can be used to read the 'culture' of the local community (Moersid Adhi, 1995). The formation of traditional markets both spatial and building layout is very related to the culture that developed in the forming community.

Traditional markets exist in Bali, originally is the forerunner of the concept of Catus Patha Space Pattern that the scope of services in the limited area of the village, but along with the times and the increase in the number of population changes the pattern of space and patterns of traders movement. The pattern of movement of these traders will affect the structure of the spatial market. Because it is formed based on local cultural concepts physically, traditional markets become unique urban formations that characterize traditional cities. This uniqueness is what makes the traditional market become objective of tourists to know more closely the daily life of the city that are visited. Of all the composition of the city center in Bali such as: Denpasar, Gianyar, and Klungkung City, which initially follow the pattern.

Traditional market as a municipal infrastructure that must be managed properly on a regular basis and sustainable, conditions are increasingly marginalized by the presence of modern markets with the completeness 
of facilities and services. Regulations that do not mention detailly the distance between traditional and modern markets lead to friction between modern and traditional markets, especially in changes in people's shopping preferences, which have implications for the pattern of community movements on the use of market trading facilities in urban areas (Fauzul Rizal Sutikno, 2009). If such developments are allowed and no attempt is made to revitalize traditional markets, then cities in Indonesia will lose their cultural uniqueness. To revitalize traditional markets, it is necessary to recognize the culture that is the basis of the market formation so that the uniqueness of traditional markets can be maintained and give the identity of cities in Indonesia.

The threatened existence of traditional markets due to the pressures of the modern market has been studied by the North Sumatra Provincial Government in 2006. This study shows that small businesses have proven to be a "buffer" to the people's economy, because these circumstances encourage community initiatives to engage in economic activities as a means of survival. Other research conducted by C Nielsen (2003) also shows the same thing, the modern market according to this study has grown by $31.4 \%$. At the same time, the traditional market will be exhausted within the next 12 years, so there is a need for preventive measures to maintain the continuity of traditional markets including the viability of trade (retail) managed by cooperatives. The deterioration of traditional markets according to Victor M. Manek Kiik (2006) is due to the not optimal traditional market. This research shows that there is a link between not optimal function of Lolowa Market and Fatubenao Market with government policy aspect, spatial physical aspect and socioeconomic aspect. These aspects are described in several factors: accessibility (road infrastructure and modes of transport), agglomeration, distribution of social and economic facilities, internal markets (physical market buildings, supporting facilities and utilities), spatial policies, community participation policies, and consumer and buyer's presence factor. Factors influencing the changes in space function were investigated by Heri Hermanto (2008) with his research case is Wonosobo Main Market Hall. The results of this study found that the factors that affect the changes in the function of space in the market is the ease of achievement, the spread of the number of buyers, and licensing, while the biggest factor effect on changes in space function in the Main Market is the spread of the number of buyers.

The revitalization of traditional markets is important in creating the uniqueness of the city. Some of the things that will be investigated in order to help create such uniqueness are (1) to identify the cultural values that underlie the formation of traditional market spatial pattern in Denpasar, Gianyar, and Klungkung; (2) Identifying Traditional Market Spatial pattern in Denpasar, Gianyar, and Klungkung at this time; and (3) identify what factors are causing the change.

\section{Concepts and Methodology}

\subsection{Concepts}

Based on the framework of the study results of the literature and concepts (Rossi, 1982; Sari, 2007; Antoniades, 1990; Wira Saputra, 2011; Almeida, 1994; Koentjaraningrat, 1981; Geertz, 1983, Claval, 1995, Djumantri, 2011, Shirvani, 1985, Rustam Hakim, 1987, Purwanto Edi, 2004, Rudy Lilananda, 1997, Sumianto 1992 1992, Kasdi, 1995, Femina, 1989), the transformation of cultural values in traditional market spatial planning in Denpasar, Gianyar and Klungkung is referred to as a change of cultural values (concept, non-physical) to the arrangement of traditional (physical) market functions both in macro spatial (market position in urban and market spatial) and micro spatial arrangements (from functioning in stalls and kiosks) from when the initial form is found and the change up to now. The category of transformation to be studied is topological (geometry) because the object is a geometric shape which is changing with the same shaping components and spatial functions. This transformation is influenced by the factors mentioned above that is: (1) Social change, (2) Cultural changes, (3) Economic change and (4) Political change. The whole concept is illustrated in the research model as follows. 


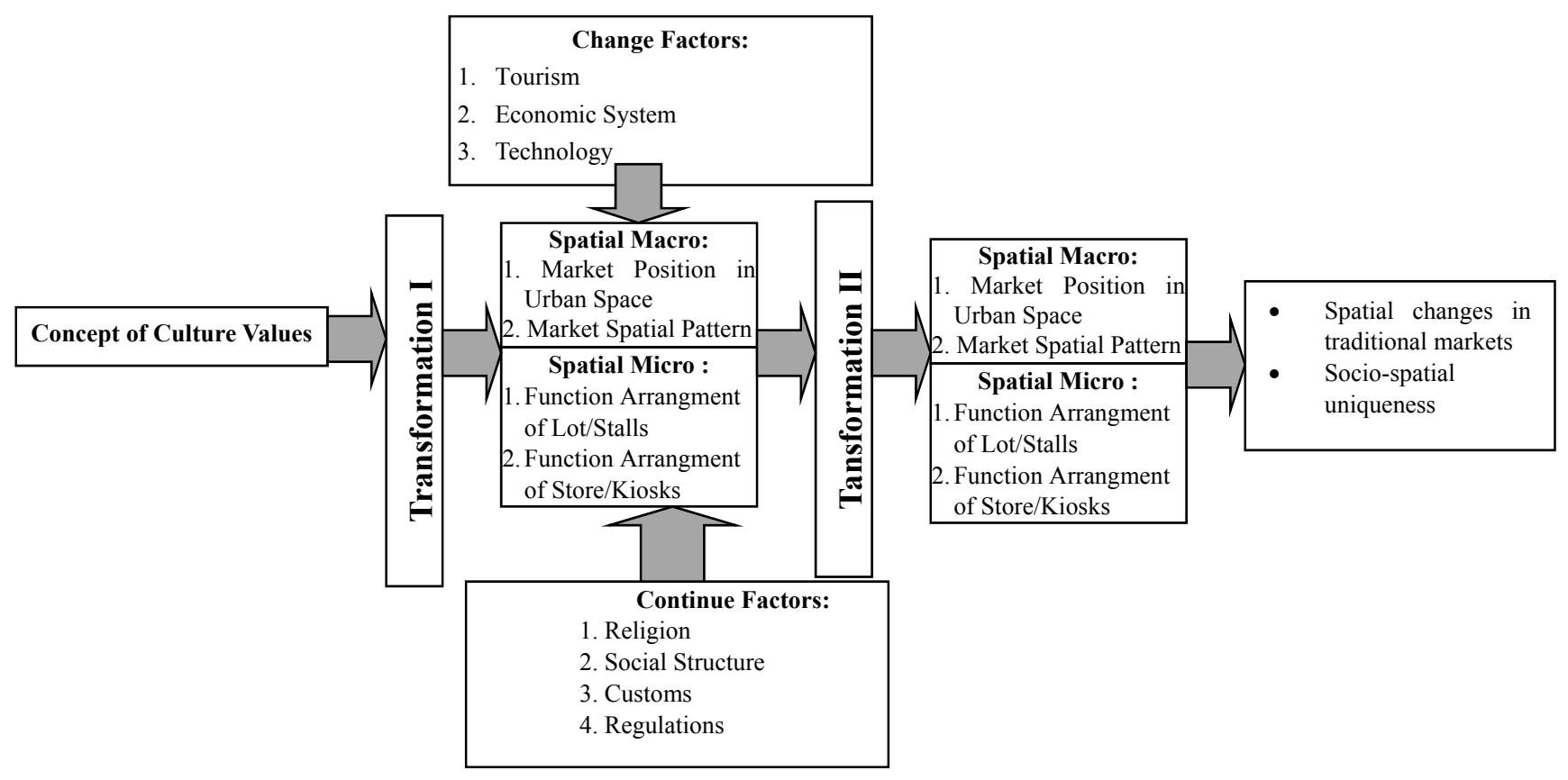

\subsection{Methodology}

This research was designed using qualitative naturalistic approach. This method is used in accordance with the needs of research that will look for local character or uniqueness that will not be generalized in the research conclusions. According to Susanne Almeida-Klein (1994: 193) there is no precise quantitative methodology of adequate economic calculations to evaluate the cultural dimension of development. Thus the method used is a qualitative method as in most social studies. The method to be used is the E-C (Environnement-Comportement) method (Zeisel, 1981) or Environment-Behavior. In this study, systematically observed the activities and interactions of buyers and traders in their environment (in this case: Traditional Market) and at the same time observed the traditional market's spatial capacity to accommodate these activities. The location of research is 3 markets located in the city center and which is the forerunner of Denpasar, Klungkung, and Gianyar City. The three markets are: Badung Market, Gianyar Market, and Semarapura Market. Observations are made of its position change in the municipal rules and morphology in the market.

\section{Results and Discussion}

With regard to the cultural role of the market society, Di Maggio in Damsar (1995) proposes three arguments: Firstly, culture forms the rational actors of the market economy; Secondly, the ideas, cognitive technologies, and institutions concerned with creating a framework for the market economy; Thirdly, people use culture to interpret and adapt to market relationships and institutions. In this research will be focused on the third argument to get the cultural value used to place the market and its facilities.

\subsection{Culture Value}

The trading activity called the market or old market in Bali, especially according to the story of the elders, takes place and takes place under the banyan tree, which is protected from the heat of the sun. Traditional markets in Bali are built on traditional village spatial arrangements arranged based on the spatial layout concept of Hindu. In that conception space is regarded as a macro cosmos which is the embodiment of the micro cosmos. The structure has the same parts: head, body and legs. They also have the same purity values as: holy for head, middle for body, and profane for the feet. At the traditional village level, the concept is transformed in the traditional Balinese village spatial structure (see figure 1). Traditional markets as part of the village, occupying parts of the body with the value of middle. Along with the palace, community building (bale banjar), and the square, the market forms the grand square of the village. 


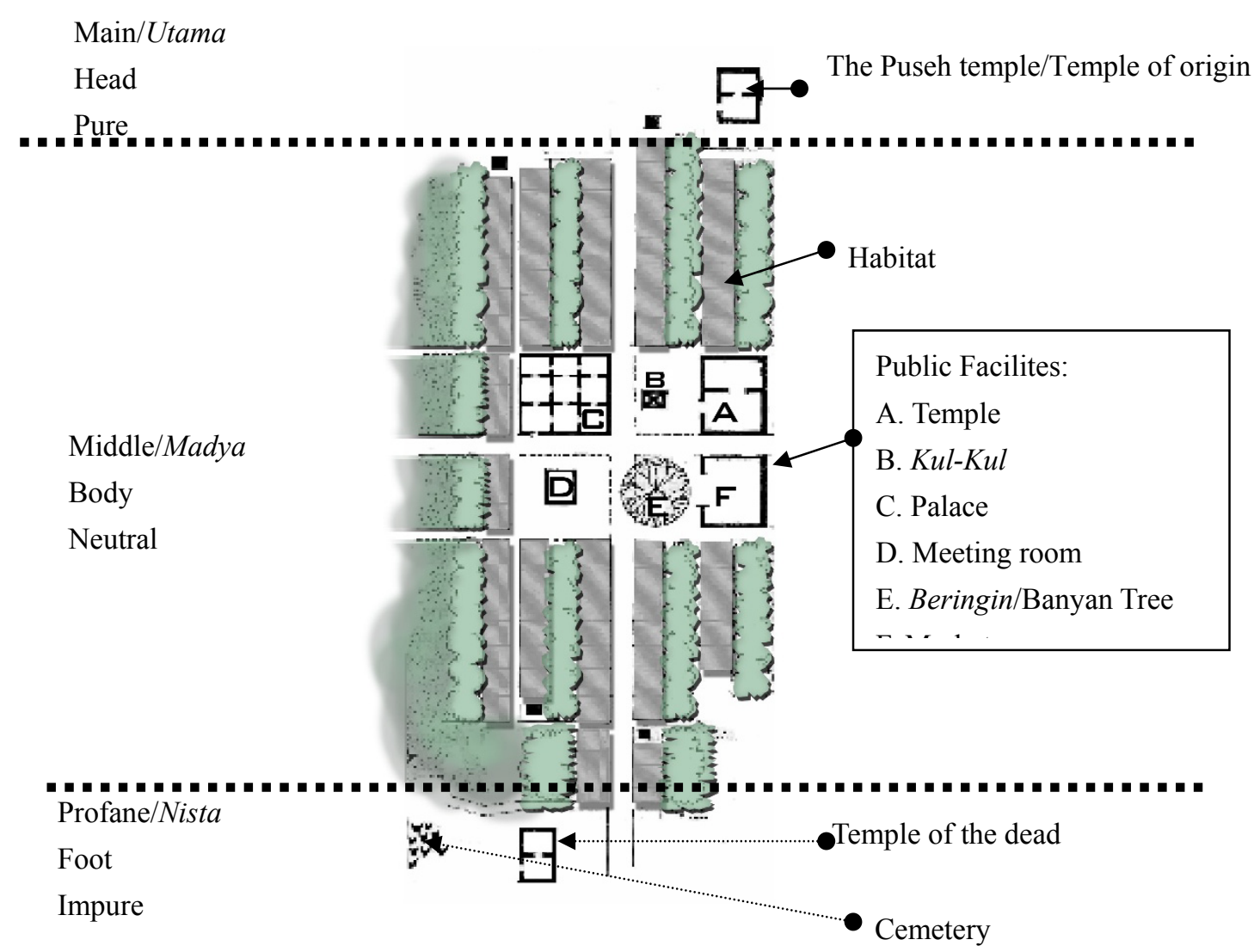

Figure 1. Spatial pattern of custom village in Bali

(Source: Saliya, 1975; Budiharjo, 1986; Gelebet, 1986; Parimin, 1986; Sularto, 1987)

The location of the market in the grand plaza depends on the location of the palace. While the location of the palace is determined by the expected cosmological value in accordance with expectations of prosperity, and glory of the kingdom. The location of the palace is good and is expected to provide prosperity for its inhabitants is to the northeast or northwest (see picture 2). Other positions have cosmological opposite effects. Based on this, then the choice of market position generally is in the southeast or southwest. Another position is still possible if not occupied the palace. 


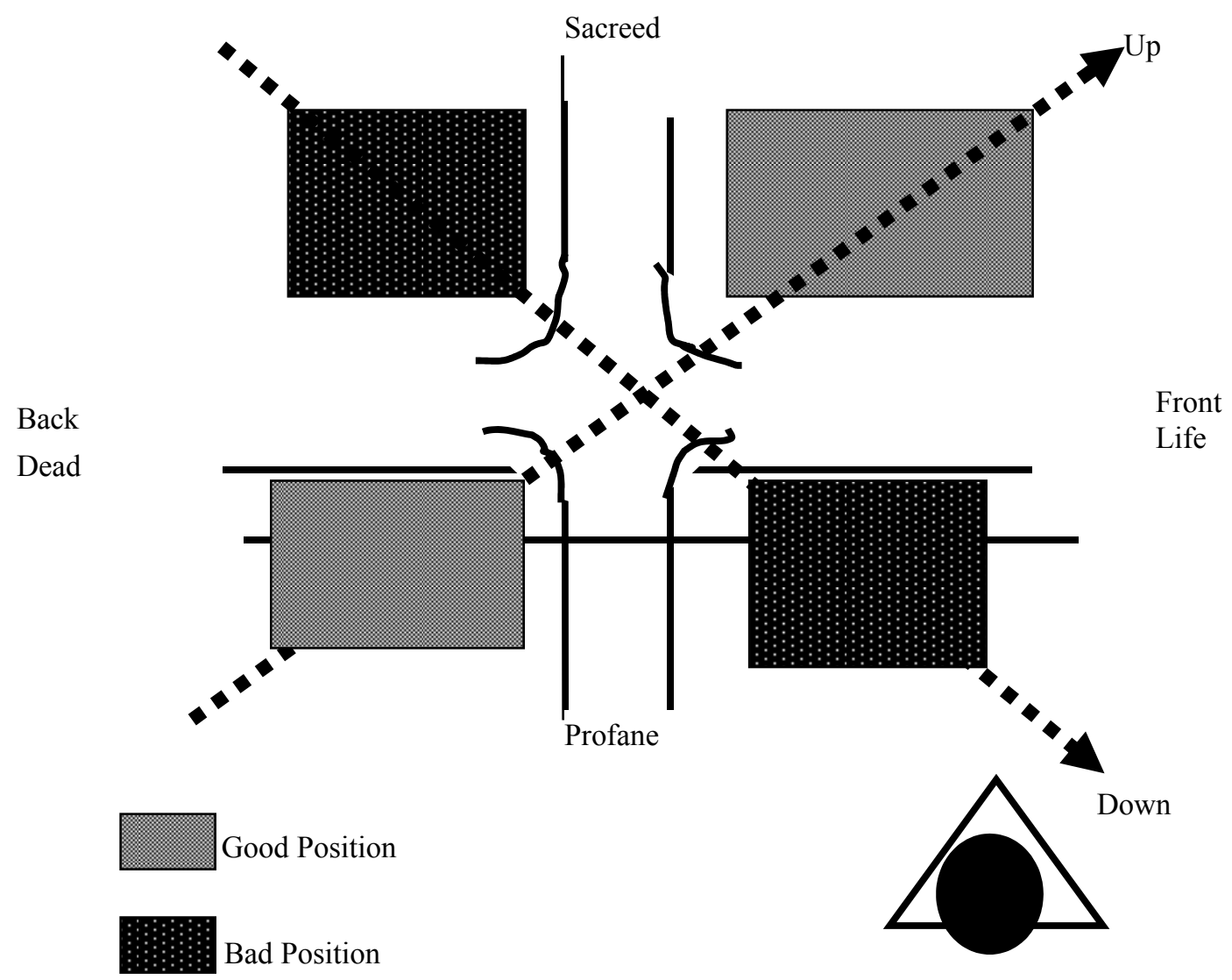

North

Figure 2 The cosmological value of the palace layout at Pempatan Agung (Main Cross Section)

(Source: Putera, 1998: 34)

Based on the values that have been described above, in general the layout of traditional markets in Bali is illustrated in Figure 3. There are two variations of the location of the market. First, there is in the northwest corner of the Main Cross Section (in Denpasar and Gianyar). Secondly, in the southeast (Bangli, Klungkung, Buleleng, Karangasem, and Tabanan). It is related to the variation of the location of the palace.

In the era of the kingdom, the market is an element of the city that has an important role for the survival of the community. This is reflected in the concept of spatial royal city that is Catus Patha (Main Cross Section) pattern. Catus patha is not just an intersection that has a sacred value but is associated also with its status as the capital of the kingdom. In its position as the center of the kingdom of this main cross section, it consists of four elements, namely (1) the palace as the kingdom as well as the center of government, (2) the market as the center of economy, (3) the public square or open space used as a recreational park, and (4) Wantilan (community building) as a cultural center (Putra, 2005: 63). 


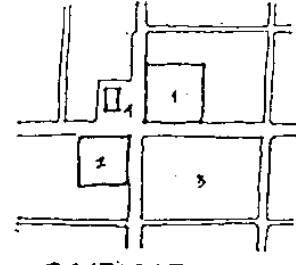

onrasar

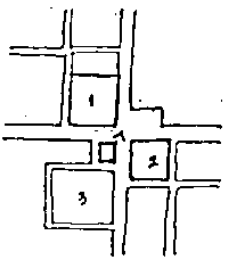

KUNGKUNG

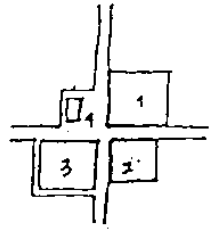

EANELI

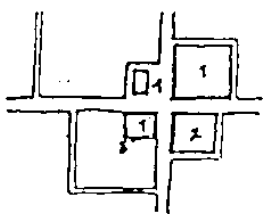

BULELENT

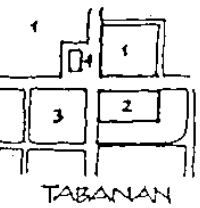

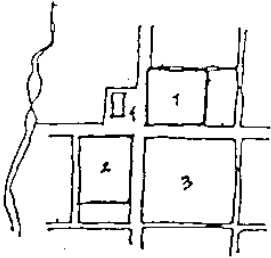

ELAMYAR

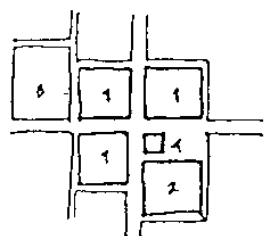

MARANEASEM

1. Palace

2. Market

3. Square

4. Community Building (Wantilan)

Figure 3. Transforming cultural values in Pempatan Agung (Main Cross Section)'s spatial plan in Bali (Source: P2R Bali, 1990)

From the composition of the city center mentioned above, the market in the Balinese cultural system is a unity of political, social, economic and defense forces of the country. It is transformed in the city center layout in Main Cross Section area. Throughout the Main Cross Section, the market is always close to the palace and the square, a spatial trilogy that is the transformation of the socio-cultural, political, and economic trilogy. Market placements dependent on the position of the palace also show that the cultural value transformed in market placement at the urban level is the cosmological value associated with the overall value of Balinese traditional architecture. Since the cosmological value is highly linked and determined by power, the cultural value in spatial urban settlement of Bali is a "cosmological-political" value.

\subsection{Traditional Market Spatial Pattern}

\section{a. Position on the city scale (macro spatial)}

The transformation of the "cosmological" political values of traditional markets in 3 cities shows clearly how the political forces determine the market position in the city center. At the beginning of its formation all the palaces lie at a good value angle on a cosmological scale. The market position follows the palace's position. But the replacement of the government changed the physical market. In the City of Denpasar the traditional market (M), which was originally located in the northwest of the Pempatan Agung (Main Cross) out of the "center" position once the royal government fell into the hands of the colonial. The traditional market of Gianyar moves from the southeast to the northwest with a spatial reduction. While the traditional market of Semarapura, Klungkung its position remains but the breadth is reduced. 


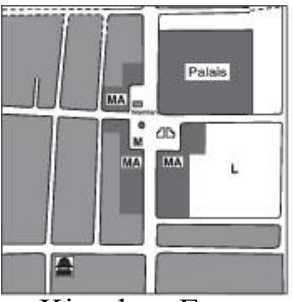

Kingdom Era

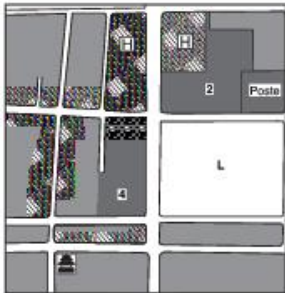

Year 1950s

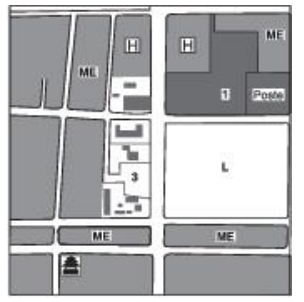

Colonial Era

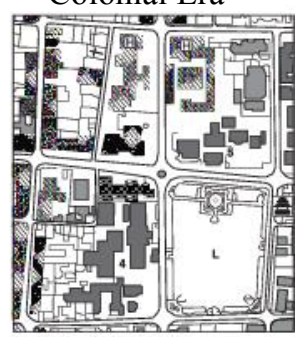

Year 2000s

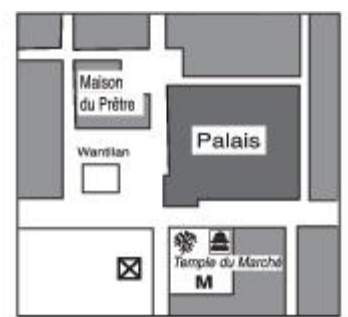

Kingdom Era

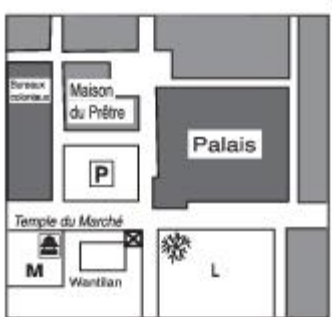

Year 1950s

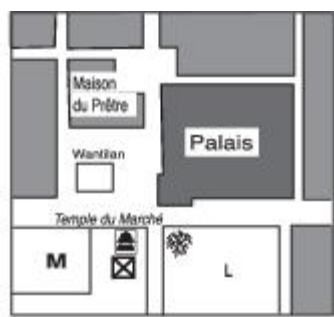

Colonial Era

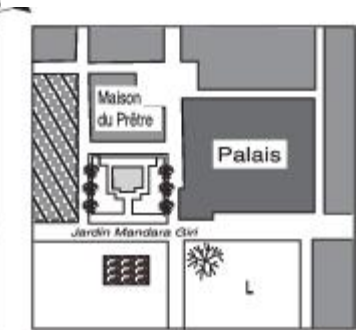

Year 2000s

Figure 4. Location of Traditional Market in Denpasar City Center (left) and Gianyar (right)

The changing market position of the above city center strengthens the role of traditional markets as part of the power trilogy and reinforces the transformation of the "cosmological" political values on the spatial city.

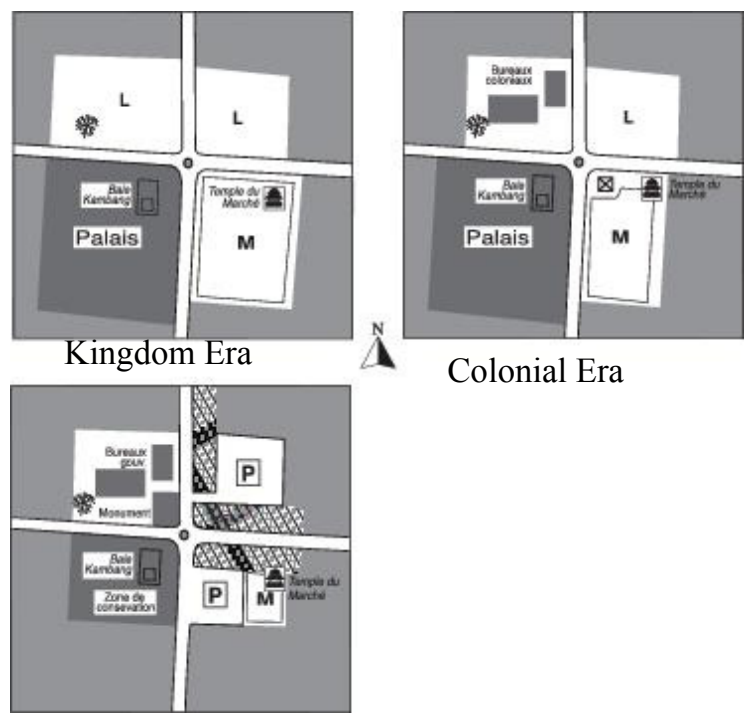

Year 2000s

Figure 5. Location of Traditional Market in Semarapura City Center, Klungkung

\section{b. Market morphology}

As traditional market positioning in the city center, traditional market morphology also follows the cosmological values of traditional Balinese architecture. The division of zoning over the sacred profane area is seen from the placement of the sacred market place (Melanting Temple). Following the placement of the temple, the placement of other functions on the market is regulated so that in the holy zone, the goods sold are those of clean commodities. But in the process of market development, there is a change of market morphology.

Badung Market has been developed physically several times. However, in terms of spatial according to cosmological values, the most prominent change is the displacement of Melanting Temple which was located in the middle of the tread, shifted to the most sacred zone of Kaja-Kangin (North-East), see figure 6. This change proves that the physical development of the market, especially in the placement of the holy place, is done to improve to a more precise position according to cosmological values. 


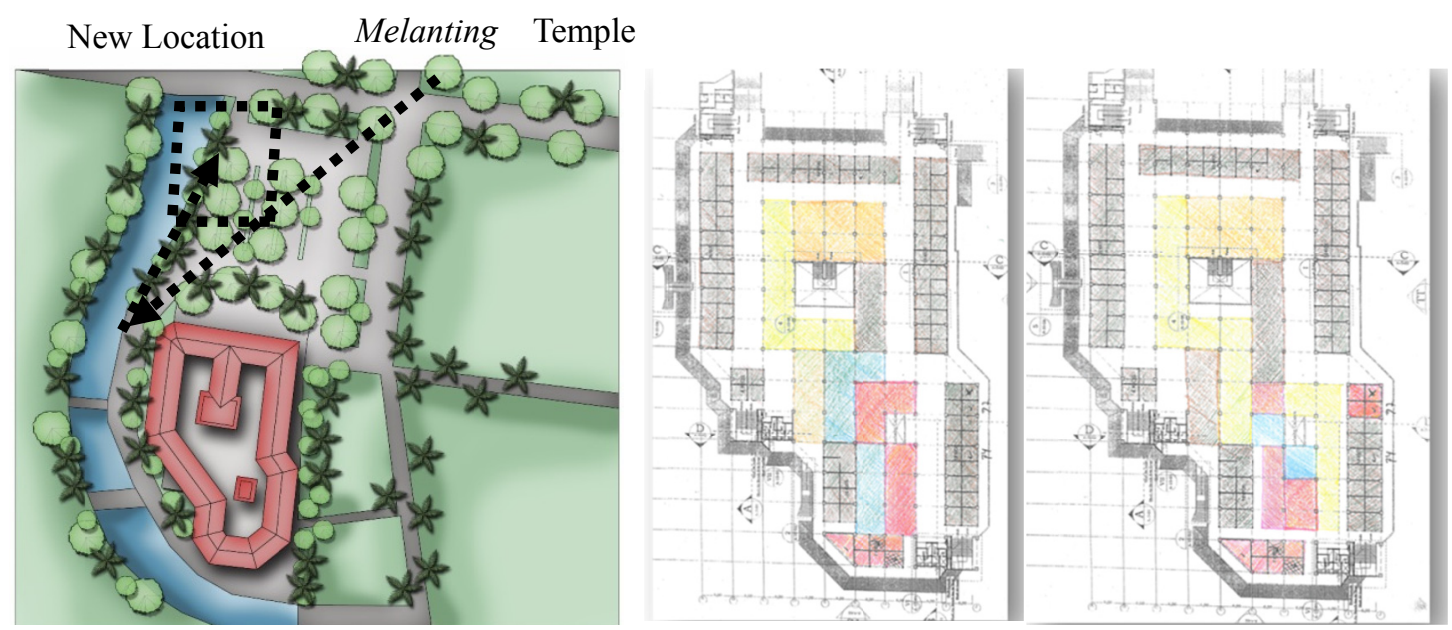

Figure 6. Morphology of Badung Market

Attempts to get the right position for the shrine are also seen in the position of Melanting Temple in Semarapura Market. When viewed from the direction of the wind this position is less precise because it is in the middle of the tread (see picture 7). But when placed in Kangin Kaja (East North) position, the temple will be located behind another building in which there is a toilet so that its holiness is in doubt. Then the temple is set at the location of the middle of the market.

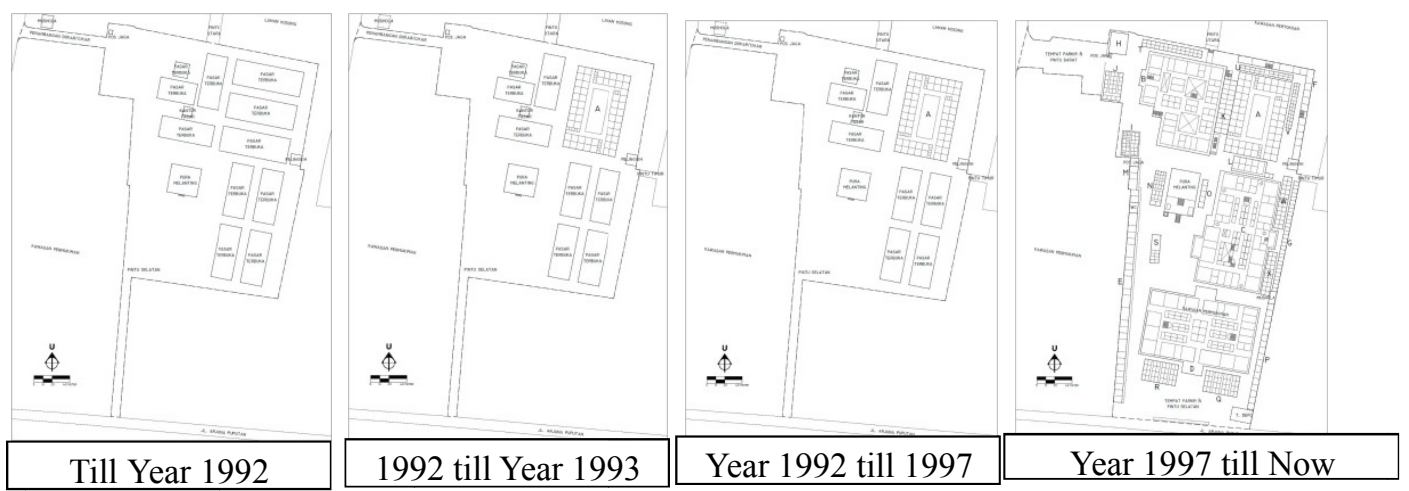

Figure 7. Changes in the morphology of Semarapura and Klungkung Market

Source: Interview with Ir. I Made Kandel, July, 2015

\section{c. Micro Spatial Pattern}

The adherence to cosmological values is not only applied to the macro level (city and market) but also on the micro level. All kiosks and stalls always place a shrine (pelangkiran) on the direction of Kaja Kangin (North East). The most sacred part in one area. It can be found both in Badung Market, Gianyar, and Semarapura. Unlike the macro level, kiosk and stalls are not affected by political conditions but fully on cosmological values. 

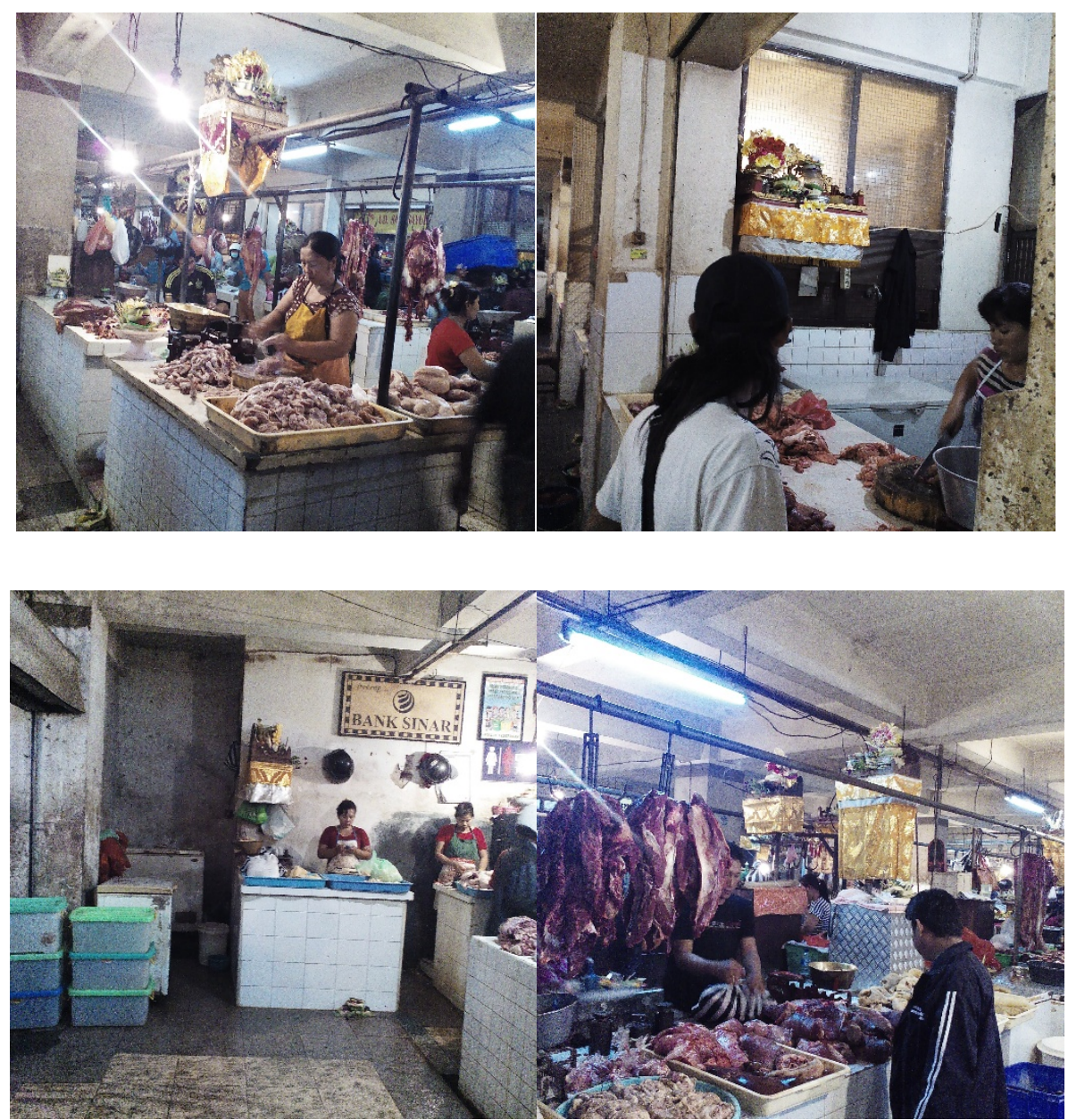

Figure 8. Variations of pelangkiran placement (shrine) on kiosks and stalls

\subsection{Factors of Change}

Based on the three cases that have been observed some changes, especially at the macro level both city and market. Types of changes include changes in location shift (Badung Market) and spatial shift (Badung and Semarapura Market). The cause of the location shift is largely due to power shifts. While the spatial shift in the market due to cultural factors where people want the placement of a holy place in accordance with the exact cosmological value.

\section{Conclusion}

Based on the results of studies that have been done in 3 cases some things that can be concluded that is:

1) The cultural values underlying the formation of market morphology are the "cosmological-political" values set in the traditional Balinese architecture spatial by placing power of palace as the main determinant. The values maintained until now are the divisions of sacred and profane layout transformed primarily in market morphology and stalls and kiosks spatial pattern.

2) Traditional market spatial pattern follows cosmological values where sacred profane division becomes important in determining the location of the shrine. This is also true in micro spatial arrangements (stalls and kiosks).

3) Factors that cause changes in spatial and market morphology are political factors and cultural factors. Political factors change the location and dimension of the market while cultural factors change the location of the shrine to get a place that is more in line with the cosmological rules.

\section{Acknowledgment}

This research can be completed with the help of various parties. Therefore, upon the completion of this study, the authors would like to thank the supporters of this research, namely: Rector of Udayana University and Head of 
LPPM which has created a system for the Study Program to allocate research budget for lecturers, Head of Architectural Studies program that has allocated the research for lecturers, students Anindya, Angga, Gus De with his friends who have helped data collection including depiction, a resource that we can not mention one by one mainly Ir. I Made Kandel.

\section{References}

Agus, E. Kajian Topologi, Morfologi dan Tipologi Pada Rumah Gadang Minangkabau, Dimensi Teknik Arsitektur. 1999.

Almeida, K. S. (1994). La dimension culturelle du développement: vers une approche pratique. UNESCO, Manutention, 241p.

Altman, Irwin; Rapoport Amos et WHOWILL, Joachim F. (dir). Human behavior and environment: advances in theory and research. vol.4: Environment and culture. New York: Plenum Press, 1980. 351 p.

Ananta Heri, S. E. M. M. dkk. (2009). Menahan Serbuan Pasar Modern. Yogyakarta: Pustaka Media.

Angga Iswara Gede. (2013). Konsepsi Tri Angga dan Tri Loka, Arsitektur Bali: Teknik Arsitektur Udayana.

Budiharjo, E. (1986). Architectural conservation in Bali. Jogyakarta: Gajahmada University Press, 113 p.

Bwiryomartono, B. P. (1995). Seni Bangunan dan seni bina kota di Indonesia. Jakarta: Gramedia, 201 p.

Djumantri. Pasar Tradisional, Ruang Masyarakat Tradisional Yang Terpinggirkan. Makalah.

Gelebet, I. N. (1985). Arsitektur Tradisional Daerah Bali. (L'architecture traditionnel balinais). Denpasar: Departemen Pendidikan dan Kebudayaan, Proyek Inventarisasi dan Dokomentasi Kebudayaan Daerah, 476 p.

Lilinanda, R. P. (1997). Transformasi Pasar Tradisional di Perkotaan. Surabaya: Fakultas Teknik Arsitektur UK Petra.

Parimin, A. P. (1986). Fundamental study on spatial formation of island village: environmental hirarchy of sacred-profane concept in Bali. Thèse de doctorat: Université Osaka.

Putra, I. G. M. (1987). Pengaruh Pariwisata dalam Perkembangan Bangunan Perumahan Tradisional Bali di Desa Bualu. Denpasar: Laporan Penelitian Universitas Udayana.

Saliya, Y. (1975). Spatial concept in balinese traditional architecture: its possibilities for future development. Thése de magister: Université of Hawai, 143 p.

Sularto, R. (1987). A brief introduction to traditional architecture of Bali, some basic norms: séminaire de «The AgaKhan Awards for Architecture». Bali.

Utami Dewi dan F. Winarni. Pengembangan Pasar Tradisional Menghadapi Gempuran Pasar Modern di Kota Yogyakarta: Proceeding Imposium Nasional ASIAN III.

\section{Copyrights}

Copyright for this article is retained by the author(s), with first publication rights granted to the journal.

This is an open-access article distributed under the terms and conditions of the Creative Commons Attribution license (http://creativecommons.org/licenses/by/4.0/). 